\title{
The GnRH system in the European sea bass (Dicentrarchus labrax)
}

\author{
N Zmora, D González-Martínez ${ }^{1}$, J A Muñoz-Cueto ${ }^{1}$, \\ T Madigou², E Mañanos-Sanchez ${ }^{3}$, S Z Doste ${ }^{3}$, Y Zohar ${ }^{4}$, \\ $\mathbf{O} \mathbf{K a h}^{2}$ and A Elizur
}

\author{
National Center for Mariculture, Israel Oceanographic and Limnological Research, PO Box 1212, Eilat 88112, Israel \\ ${ }^{1}$ Departamento de Biología Animal, Vegetal y Ecología, Facultad de Ciencias del Mar, Universidad de Cádiz, 11510 Puerto Real, Spain \\ ${ }^{2}$ Endocrinologie Moléculaire de la Reproduction, UMR CNRS 6026, Université de Rennes 1, Campus de Beaulieu, 35042 Rennes cedex, France \\ ${ }^{3}$ Instituto de Acuicultura de Torre de la Sal, CSIC, 12595 Ribeira de Cabañes, Castellón, Spain \\ ${ }^{4}$ Center of Marine Biotechnology, University of Maryland, Biotechnology Institute, 701 East Prat St, Baltimore, Maryland 21202, USA \\ (Requests for offprints should be addressed to N Zmora; Email: nilli@ocean.org.il) \\ (A Elizur is now at Bribie Island Aquaculture Research Center, Queensland Department of Primary Industries, Queensland 4507, Australia)
}

\begin{abstract}
The cDNA sequences encoding three GnRH forms, sea bream GnRH (sbGnRH), salmon GnRH (sGnRH) and chicken GnRH II (cGnRH II), were cloned from the brain of European sea bass, Dicentrarchus labrax. Comparison of their deduced amino acid sequences to the same forms in the gilthead sea bream, Sparus aurata, and striped bass, Morone saxatilis, revealed high homology of the prepro-cGnRH II (94\% and 98\% respectively), and prepro-sGnRH (92\% to both species). The sbGnRH exhibited dissimilar identities, with high homology to the striped bass (93\%), and lower homology (59\%) to the gilthead sea bream. Two transcript types were identified for the GnRH-associated peptide (GAP)-sGnRH as well as for the GAP-cGnRH II, which suggests a possible alternative splicing followed by the addition of an early stop codon. In order to obtain antibodies specific for the three GnRH precursors, recombinant GAP proteins were produced. The differential expression of the three GnRHs previously reported in the brain by means of in situ
\end{abstract}

hybridization, using riboprobes corresponding to the GAP-coding regions, was fully confirmed by immunocytochemistry using antibodies raised against the recombinant GAP proteins, indicating that the transcripts are translated into functional proteins. Moreover, this approach allowed us to follow, for the first time, the specific projections of the different cell groups: sGAP fibers are distributed mainly in the forebrain with few projections reaching the pituitary, sbGAP fibers are mainly present in the preoptic area, mediobasal hypothalamus and predominantly project to the pars distalis of the pituitary, whereas cGnRH II fibers have a widespread distribution primarily in the posterior brain, and do not project to the pituitary. These new tools will be extremely useful to study further the development, regulation and functional significance of three independent $\mathrm{GnRH}$ systems in the brain of vertebrate species.

Journal of Endocrinology (2002) 172, 105-116

\section{Introduction}

Gonadotropin releasing hormone (GnRH) is a neuropeptide known to regulate gonadotropin expression and secretion in vertebrates. To date, fourteen forms of $\mathrm{GnRH}$ decapeptides have been found in vertebrates, in which at least one unique form has been determined from a representative species of all vertebrate classes. Ten GnRH forms out of the fourteen were found in fish and six of them in teleosts: chicken GnRH II (cGnRH II; Miyamoto et al. 1984), mammalian GnRH (mGnRH; Matsuo et al. 1971, Burgus et al. 1972), salmon GnRH (sGnRH; Sherwood et al. 1983), catfish GnRH (cfGnRH; Ngamvongchon et al. 1992), sea bream GnRH (sbGnRH; Powell et al. 1994), herring GnRH (hGnRH; Carosfeld et al. 2000) and Medaka GnRH (mdGnRH; Okubo et al. 2000). cGnRH II is present in all vertebrate classes examined to date, and the $\mathrm{mGnRH}$ form is present in primitive non-teleostean bony fish, primitive teleosts (eels and others), amphibians and mammals. sGnRH, cfGnRH and $\mathrm{sbGnRH}$ are found in higher teleosts. This taxonomic distribution indicates that $c \mathrm{GnRH}$ II and $\mathrm{mGnRH}$ are ancient vertebrate forms that gave rise to other variants.

The typical structure of the GnRH precursor protein consists of 1) a signal peptide at the N-terminal (about 23 amino acids (aa) in size), 2) the GnRH decapeptide which is the bioactive peptide, followed by a 3 aa cleavage site (Gly-Lys-Arg) and 3) a GnRH-associated peptide (GAP) at the C-terminal (about 60 aa in size). The bioactive 
Table 1 Oligonucleotides used for PCR amplification of the three GnRH forms

\begin{tabular}{|c|c|c|c|}
\hline \multirow[b]{2}{*}{ No. } & Primer & Sequence & Direction \\
\hline & & & \\
\hline 1 & $\mathrm{Ol}$ dG Ad2 & 5'AAGCTTGAATTCGGATCCC $(\mathrm{G} \times 17) 3^{\prime}$ & $\mathrm{F}$ \\
\hline 2 & Adap2 & 5'AAGCTTGAATTCGGATCCC $3^{\prime}$ & $\mathrm{F}$ \\
\hline 3 & SB-5' & 5'ACCTGAGCAAGAAGAATGGCT3' & $\mathrm{F}$ \\
\hline 4 & S-5' & 5'GTTGTTGGCGTTGGTGG3' & $\mathrm{F}$ \\
\hline 5 & Cll-5' & 5'CTCGGGCTGCTTCTATGTGT3' & $\mathrm{F}$ \\
\hline 6 & sbGAP-5' & 5'CATATGGGGAAG(AG)GGGA(AC)CTGGACG3' & $\mathrm{F}$ \\
\hline 7 & sGAP-5' & 5'CATATGGGGAAGAGAAG(CT)GTGGGAGA3' & $\mathrm{F}$ \\
\hline 8 & CllGAP-5' & 5'CATATGGGCAAGAGGGAACTGGACTCTTT3' & $\mathrm{F}$ \\
\hline 9 & sbGAP-3' & 5'GGATCCTCATTT(TC)TT(AG)TAXGTTCTG(TG)GTCC3' & $\mathrm{R}$ \\
\hline 10 & sGAP3' & 5'GGATCCTCA(TA)TT(AG)TT(CA)GGGAACCT(CT)TT(CT)TT3' & $\mathrm{R}$ \\
\hline 11 & CllGAP-3' & 5'GGATCCTCACTTССТСТTСTGGAGСТC3' & $\mathrm{R}$ \\
\hline 12 & sbGAP-3'2 & 5'TCСGTTСТСССТGTCAGTGAC3' & $\mathrm{R}$ \\
\hline 13 & sGAP-3'2 & 5'TCGGTCAAAATGACTGGAATC3' & $\mathrm{R}$ \\
\hline 14 & CllGAP-3'2 & 5'TCTGGCTAAGGCATCCAGAATG3' & $\mathrm{R}$ \\
\hline 15 & Ol dT Adap & 5'GACTCGAGTCGACATCGA $(T \times 17) 3^{\prime}$ & $\mathrm{R}$ \\
\hline
\end{tabular}

Ol dG Ad2, oligo d-G adaptor 2; Adap2, adaptor 2; Ol dT Adap, oligo dT-adaptor; F, forward; R, reverse. Nucleotides in brackets indicate degeneracy.

decapeptide is processed from the precursor by removal of the signal peptide and cleavage at the dibasic aa (Lys-Arg) (Klungland et al. 1992). The GnRH decapeptide is highly conserved at positions 1-4, 6, 9-10 (Sower 1997). While the decapeptide sequence of any GnRH form is highly conserved among species, the signal peptide and the GAP are more diverse both in their amino acid and nucleotide sequences. Although still controversial, the function of the GAP is believed to be restricted to providing the correct secondary structure for precise processing of the GnRH precursor (Sherwood et al. 1994).

It is now well established that at least two GnRH forms are present in the brain of one species, with modern teleosts expressing three GnRH forms. In some perciforms, such as gilthead and red sea bream, striped bass, tilapia as well as the European sea bass, the three GnRH forms were found to be sGnRH-[Trp $\left.{ }^{7}, \mathrm{Leu}^{8}\right] \mathrm{GnRH}$, cGnRH II- $\left[\mathrm{His}^{5}, \mathrm{Trp}^{7}, \mathrm{Tyr}^{8}\right] \mathrm{GnRH}$ and sbGnRH[Ser ${ }^{8}$ GnRH (Powell et al. 1994, Gothilf et al. 1995, Okuzawa et al. 1997, Parhar 1997, Chow et al. 1998). However, as a primitive teleost such as the herring also expresses three GnRH variants (Carosfeld et al. 2000), the presence of three GnRHs could be a general feature in teleosts. The three forms are expressed by different genes located on different chromosomes. Until now, their expression sites have been studied primarily by in situ hybridization and showed a differential pattern of expression, with sGnRH being expressed mainly in the olfactory system, sbGnRH in the preoptic area and cGnRH II in the tegmentum of the midbrain. This pattern was found in sea bream (Gothilf et al. 1996), African cichlid (White et al. 1995) and red sea bream (Okuzawa et al. 1997), and recently in the European sea bass (González-Martínez et al. 2001). However, there is little information regarding the respective projections of these different cell populations since in situ hybridization only provides information on the localization of the transcripts. Immunohistochemistry detection of different, but highly related, GnRH forms encounters severe problems of antibody specificity, which can be overcome in species expressing two GnRH forms but become critical when dealing with three peptides.

Therefore, the aims of this work were to characterize the cDNAs encoding for the GnRH forms present in the European sea bass brain, to produce antibodies against their respective recombinant GAPs and to check their suitability for the study of the expression sites of different GnRHs by means of immunohistochemistry. This strategy was developed because of the divergence of the GAPs within the same species and because the distribution of immunoreactive GAPs was consistently reported to be similar to that of immunoreactive GnRH (Bloch et al. 1992, Ronchi et al. 1992, Polkowska \& Przekop 1993).

\section{Materials and Methods}

Isolation of European sea bass GnRH and GAP cDNAs: salmon, sea bream and chicken II forms

Total RNA was extracted from the brain of sexually mature female sea bass using a scaled-down guanidinium isothiocyanate method (Chomczynski \& Sacchi 1987). cDNA was synthesized using $1 \mu \mathrm{g}$ total RNA, AMV reverse transcriptase (Promega, Madison, WI, USA) and the universal oligo dT-adaptor primer (Frohman 1990) (no. 15, Table 1). Prior to use in $5^{\prime}$ RACE, the cDNA was tailed with terminal deoxy transferase (Promega) using dCTP.

Primers specific for each GAP form were designed according to the striped bass GAP sequences (Genbank 
accession numbers: sbGnRH, AF056314; cGnRH II, AF056313; sGnRH, Y Zohar, personal communication). The first PCR amplification was carried out using primers located $5^{\prime}$ to the GAP sequence (Table 1: nos 3, 4, 5), followed by a nested PCR using a set of primers designed for the amplification of the full length GAP sequence (nos 6 and 9 for sbGAP, nos 7 and 10 for sGAP, nos 8 and 11 for cIIGAP). The nested primers contained specific restriction sites and a stop codon in the $3^{\prime}$ primer to facilitate introduction into an expression vector.

The full-length cDNA sequences of the three GnRH forms were isolated by $5^{\prime}$ RACE PCR amplification. 3' gene specific primers (nos $9,10,11)$ and oligo d-G adaptor 2 (no. 1) amplified oligo-dC tailed cDNA template. Nested PCR amplification was carried out using adaptor 2 (no. 2) and $3^{\prime}$ gene specific primers (nos 12, 13, 14). The total PCR products were cloned into pGem-T easy vector (Promega) and the clones containing the GnRH cDNA were identified by colony hybridization using the corresponding specific GAP sequence as a probe.

All PCR reactions were carried out in $25 \mu \mathrm{l}$ using 1 unit Taq DNA polymerase (Promega), buffer (Promega), $1.5 \mathrm{mM} \mathrm{MgCl}_{2}$, nucleotides $(0.2 \mathrm{mM}$ final concentration of each nucleotide), $12.5 \mathrm{pmol}$ of each primer and in a final dilution of 1:50 cDNA. Cycling parameters were: 3 min denaturation at $94^{\circ} \mathrm{C}$ followed by 30 cycles of 1 min denaturation at $94^{\circ} \mathrm{C}, 1 \mathrm{~min}$ annealing at $50{ }^{\circ} \mathrm{C}$ and $1 \mathrm{~min}$ extension at $72^{\circ} \mathrm{C}$ (last extension step lasted $10 \mathrm{~min})$.

The chosen PCR products were isolated by excision from agarose gel or direct clearing from PCR reaction using purification kits (gel extraction kit or PCR purification kit, Qiagen, Hilden, Germany). The products were ligated into pGEMT-Easy plasmid (Promega) and transformed into $\mathrm{DH}_{5} \alpha$ Escherichia coli cells. Colonies carrying the relevant insert were identified either by colony hybridization or by examining insert size, followed by sequencing.

\section{DNA sequencing}

Double stranded plasmid DNA was sequenced either using the Sequenase version II kit (Amersham Pharmacia Biotech AB, Uppsala, Sweden) or using enzyme F S Taq dye deoxy terminator cycle sequencing at the DNA Sequencing Biological Services (Weizmann Institute, Rehovot, Israel). Universal primers, SP6 and T7, as well as gene-specific primers were used to obtain the complete sequence of both DNA strands.

\section{Production of recombinant GAP proteins}

The sequences encoding for the three GAPs were engineered into the PQE-31 expression vector (Qiagen) which contains a $6 \times$ His residue tag $5^{\prime}$ to the polylinker and produces $\mathrm{N}$-terminal $6 \times$ His tagged recombinant proteins. The processes of ligation, transformation into M15 [pREP4] cells, expression of the protein and purification (using NI-NTA agarose columns) were performed using the QIAexpress kit (Qiagen) under denaturing conditions, according to the manufacturer's protocol.

The sequence encoding for the cIIGAP was engineered into pGEX-2 expression vector by using a $5^{\prime}$ gene-specific primer (5'GAATTCCAGGCAAGAGGGAACTG3') which was designed especially for insertion in the correct reading frame. This system expresses a recombinant protein which is fused in its N-teminal end to gluthathione transferase. The construct was transformed into $\mathrm{DH}_{5} \alpha$ E. coli cells which were grown in the presence of ampicillin $(50 \mu \mathrm{g} / \mathrm{ml})$. Protein expression was induced by addition of $1 \mathrm{mM}$ IPTG and further incubation for $3 \mathrm{~h}$. The bacterial cells were then harvested by centrifugation $\left(5000 \mathrm{~g}, 15 \mathrm{~min}, 4^{\circ} \mathrm{C}\right)$, the pellet was frozen overnight at $-20{ }^{\circ} \mathrm{C}$ and resuspended in $10 \mathrm{ml}$ ice-cold PBS $/ 50 \mathrm{ml}$ bacterial culture. Cells were lysed in the presence of lysozyme $(20 \mu \mathrm{g} / \mathrm{ml})$ for $45 \mathrm{~min}$ on ice, followed by $5-6$ rounds of $15 \mathrm{~s}$ sonication (Microson cell disruptor model XL2005, microprobe $2.4 \times 11.5 \mathrm{~mm}$ at level 18 of the scale). Triton X-100 was added to the supernatant to a final concentration of $1 \%$ followed by centrifugation at $10000 \times \boldsymbol{g}$ for $5 \mathrm{~min}$ at $4{ }^{\circ} \mathrm{C}$.

One milliliter of a $50 \%$ slurry of gluthathione-agarose beads (Sigma, St Louis, MO, USA) was added to the supernatant and the sample mixed for $2 \mathrm{~min}$. The beads were then washed twice by adding $50 \mathrm{ml}$ cold PBS and centrifuged for $10 \mathrm{~s}$ at $500 \times \mathrm{g}$. Fused recombinant protein was eluted with $1 \mathrm{ml} 50 \mathrm{mM}$ Tris/ $\mathrm{Cl}(\mathrm{pH} 8 \cdot 0) / 5 \mathrm{mM}$ reduced gluthathione, mixed for $2 \mathrm{~min}$ and centrifuged for $10 \mathrm{~s}$ at $500 \times \mathrm{g}$.

\section{Generation of specific antibodies against recombinant GAPS}

The purified recombinant GAPs were used for the immunization of guinea pigs. Nine female guinea pigs (5/6 weeks old; 345-365 g), three for each GAP, were acclimated for one week before the beginning of the immunization protocol. Each injection consisted of $25 \mu \mathrm{l}$ recombinant GAP $(1 \mu \mathrm{g} / \mu \mathrm{l}), 75 \mu \mathrm{l}$ distilled water, and $100 \mu \mathrm{g}$ incomplete Freund's adjuvant. Preimmune sera were collected on the day of the first injection and stored at $-20{ }^{\circ} \mathrm{C}$. The first injection was intradermal in the back (6-7 points) and the others, at one month intervals, were given intramuscularly in the hind legs. Eight days after the fourth injection, blood was collected under anesthesia by cardiac puncture, centrifuged and the serum was stored at $-25^{\circ} \mathrm{C}$.

\section{Dot blot analysis for antibodies specificity}

The specificity of antisera was assessed by dot blot analysis using the recombinant sGAP, sbGAP and cIIGAP proteins as antigens. Recombinant GAP proteins $(6-12 \mu \mathrm{g})$ were 
added to individual nitro-cellulose filters. The slices were blocked for $1 \mathrm{~h}$ in Tris-buffered saline buffer (TBS; $25 \mathrm{mM}$ Tris, $140 \mathrm{mM} \mathrm{NaCl}, 2 \cdot 7 \mu \mathrm{M} \mathrm{KCl}, \mathrm{pH} 7 \cdot 4$ ) containing 5\% non-fat dry milk. Samples were then incubated for $12 \mathrm{~h}$ with the primary antisera at a 1:2000 dilution followed by several washes with TBS containing $0.05 \%$ Tween 20. The slices were incubated for $1 \mathrm{~h}$ in peroxidase-conjugated anti-guinea pig IgG (Jackson ImmunoResearch Laboratories, West Grove, PA, USA) in 1:3000 dilution, and washed as before. The filter was developed in 0.024\% 4-chloro-1-naphthol (Sigma) in the presence of $0.002 \% \mathrm{H}_{2} \mathrm{O}_{2}$ in $50 \mathrm{mM}$ Tris buffer.

\section{In situ hybridization}

The in situ hybridization procedure was according to the Anglade et al. (1993) protocol. Two vitellogenic females and two spermiating males were used in the process, as described in detail by González-Martínez et al. (2001). It is important to note the use of riboprobes corresponding to the three GAP regions.

\section{Immunohistochemistry}

Fish (two males and two females) were anesthetised with 2-phenoxyethanol (Sigma) and perfused via the aortic bulb with Bouin's fixative (4\% paraformaldehyde and $0 \cdot 2 \%$ picric acid in $0.1 \mathrm{M}$ phosphate buffer, $\mathrm{pH} 7 \cdot 4$ ). Brains, with the pituitary gland attached, were then removed and post-fixed in the same fixative for $5-7 \mathrm{~h}$ in the dark at $4{ }^{\circ} \mathrm{C}$. After overnight cryoprotection in $0 \cdot 1 \mathrm{M}$ phosphate buffer containing 15\% sucrose, brains were embedded in Tissue-Tek, frozen in cold isopentane and serial coronal and sagittal sections of $16 \mu \mathrm{m}$ thick were obtained with a cryostat.

Immunohistochemical staining was performed using a streptavidin-biotin-peroxidase complex method. Endogenous peroxidase activity was blocked with $1 \%$ hydrogen peroxide in Coons buffer (CBT, 0.01 M Veronal, 0.15 M $\mathrm{NaCl}$ ) containing $0 \cdot 1-0 \cdot 2 \%$ Triton $\mathrm{X}-100$ for $30 \mathrm{~min}$. Before immunostaining, sections were transferred for 5 min to $\mathrm{CBT}$ and then saturated in CBT containing 0.5\% casein for $30 \mathrm{~min}$. The sections were incubated overnight in a moist chamber at room temperature with anti-sGAP, anti-sbGAP and anti-cIIGAP antisera $(1: 500,1: 1000$ dilution in $\mathrm{CBT} / 0.5 \%$ casein). The sections were then washed in CBT $(2 \times 15 \mathrm{~min})$ and incubated for $1.5 \mathrm{~h}$ at room temperature with Biotin-sp-Conjugated-AffiniPure Goat Anti-GuineaPig-IgG (Jackson ImmunoResearch Laboratories) diluted 1:1000 in CBT. After washing in CBT $(2 \times 15 \mathrm{~min})$, the sections were incubated for $1.5 \mathrm{~h}$ at room temperature with peroxidase-conjugatedstreptavidin complex (Jackson ImmunoResearch Laboratories) diluted 1:1000 in CBT. Finally, the sections were washed in CBT followed by Tris- $\mathrm{HCl}(0 \cdot 05 \mathrm{M}, \mathrm{pH} 7 \cdot 4)$ and peroxidase activity was visualized either in $0.05 \mathrm{M}$
Tris- $\mathrm{HCl}$, pH 7.6 containing 0.025\% 3,3 diaminobenzidine tetrahydrochloride (Sigma) and 0.01\% hydrogen peroxide or in 0.04\% 4-chloro-1-naphthol (Sigma) and $0.01 \%$ hydrogen peroxide. To confirm the specificity of the immunostaining, controls were performed by replacement of primary antisera with the corresponding preimmune sera and omission of primary or biotinylated antisera.

Both in situ hybridization and immunohistochemical sections were analyzed on a Leica photomicroscope and computer images were obtained with a Sony DKC-CM30 digital camera (Sony, Japan). The software used was Adobe Photoshop 5.0 and no subsequent alterations have been made. The determination of brain nuclei was made using a sea bass brain atlas (J M Cerdá-Reverter, S Zanuy \& J A Muñoz-Cueto, unpublished results).

\section{Results}

Isolation of the cDNA sequences encoding three $\mathrm{G} n \mathrm{RH}$ forms

PCR was used to amplify the cDNA sequences encoding the $5^{\prime}$ untranslated region (UTR), signal peptide, GnRH decapeptide, GAP and 3' UTR of sGnRH, sbGnRH and cGnRH II (the latter is missing the $3^{\prime}$ UTR). $5^{\prime}$ and $3^{\prime}$ RACE were carried out on both hypothalamus and brain total RNA.

Salmon GnRH The sGnRH cDNA was amplified using 5' RACE and 3' RACE. Two types of clones were obtained, one was $357 \mathrm{bp}$ in length and contained $108 \mathrm{bp}$ of the $5^{\prime}$ UTR. The second was $255 \mathrm{bp}$ in length and contained only the last $6 \mathrm{bp}$ of the UTR. The presence of the two 5' RACE products was RNA dependent rather than RT/PCR dependent. This may indicate the presence of more than one potential transcription initiation. The full cDNA sequence consisting of $567 \mathrm{bp}$ of the prepro sGnRH can be found in Genbank accession number AF224280. The cDNA sequence shows a high homology of $88-92 \%$ when compared with sGnRH precursors of other fish. The signal peptide identity is $78-83 \%$ and the GAP identity is $89-95 \%$ (Table 2).

Sea bream GnRH The sbGnRH sequence was amplified using 5' RACE and 3' RACE. The full cDNA sequence of $394 \mathrm{bp}$, encoding for 99 aa, can be found in Genbank accession number AF224279. The cDNA sequence identity compared with other teleost sbGnRH precursors ranges from $50 \%$ in the case of the African cichlid to $92 \%$ in the striped bass. The leader peptide identity ranges from $32-86 \%$ and the GAP homology ranges from 35 to $94 \%$ (Table 2)

cGnRH II The cGnRH II cDNA sequence of $462 \mathrm{bp}$ in length that encodes for 85 aa of prepro-cGnRH II was amplified using $5^{\prime}$ and $3^{\prime}$ RACE. The nucleotide 
Table 2 Comparison of the signal peptide and GAP nt sequences of the sea bass with the striped bass, sea bream and African cichlid expressed as a percentage

\begin{tabular}{|c|c|c|c|c|c|c|}
\hline & \multicolumn{6}{|l|}{ GnRH forms } \\
\hline & \multicolumn{2}{|l|}{ Salmon } & \multicolumn{2}{|l|}{ Sea bream } & \multicolumn{2}{|l|}{ Chicken II } \\
\hline & Signal peptide & GAP & Signal peptide & GAP & Signal peptide & GAP \\
\hline \multicolumn{7}{|l|}{ Fish species } \\
\hline Striped bass & $82 \cdot 6$ & $94 \cdot 7$ & $86 \cdot 4$ & $93 \cdot 7$ & 100 & $98 \cdot 1$ \\
\hline Sea bream & $82 \cdot 6$ & 93 & $31 \cdot 9$ & $57 \cdot 2$ & $91 \cdot 3$ & $96 \cdot 2$ \\
\hline African cichlid & $78 \cdot 3$ & $89 \cdot 5$ & $59 \cdot 1$ & $35 \cdot 1$ & $88 \cdot 3$ & $88 \cdot 5$ \\
\hline
\end{tabular}

sequence and the deduced amino acids sequence are available in Genbank accession number AF224281. The cGnRH II cDNA sequence shows high homology to other fish cGnRH II precursors, which ranges from $88 \%-99 \%$. The cGnRH II leader peptide of the striped bass is completely homologous to that of the sea bass and the GAP sequences differ in only one amino acid. Comparison with the African cichlid and the sea bream preprocGnRH II shows a slightly lower homology, which ranges from $88-96 \%$ (Table 2).

\section{Salmon-, sea bream- and chicken II-GAPS}

To raise anti-GAP specific antibodies, recombinant GAP proteins of each form were prepared in a bacterial expression system. The sequences encoding the three GAPs were amplified by PCR using GAP-specific primers (Table 1). Primers 7 and 10 for the sGAP, primers 6 and 9 for the sbGAP and primers 8 and 11 for the cIIGAP were used.

Salmon GAP Two transcripts of salmon GAP were amplified, one of $174 \mathrm{bp}$ and the other of $681 \mathrm{bp}$. The larger product, which appeared to be more abundant, was an unprocessed mRNA GAP. Partial or full length introns 2 and 3 were recognized by the invariant GT and AG dinucleotides found in the $5^{\prime}$ and $3^{\prime}$ intron borders. Intron 2 containing $205 \mathrm{bp}$ was located after amino acid 13, and intron 3 with $302 \mathrm{bp}$ was located after amino acid 40 of the GAP. The short product encodes the predicted 56 amino acids of the GAP. However, a stop codon (tga) present in intron 2 may give rise to the translation of a shorter GAP peptide i.e. 10 amino acids (Fig. 1A).

Chicken II GAP RT-PCR amplification of the cIIGAP resulted in two transcripts, one of $450 \mathrm{bp}$ and the other of $156 \mathrm{bp}$. Similar to the case of the sGAP, the $450 \mathrm{bp}$ product of the cIIGAP appeared to contain introns 2 and 3. Again, an early stop codon (TAA) was found, which is located in exon 3 and may encode for a different peptide of 46 amino acids. Intron 2 spanned $77 \mathrm{bp}$, located after aa 12 of the GAP, and intron 3, $196 \mathrm{bp}$, located after aa 40. The small PCR product was the fully processed form (Fig. 1B).
Sea bream GAP Only one transcript of the sbGAP was obtained by PCR amplification using primers 6 and 12 . The transcript was $177 \mathrm{bp}$ in length and seemed to be the fully processed form which encodes the predicted 59 amino acids of the GAP.

The RT-PCR product presented here represents mRNA and not genomic contamination for the following reasons: 1) the sGAP larger product was much more abundant than the smaller one, and 2) using the cDNA for sbGAP amplification resulted in only one transcript. Thus, it is possible that the larger products are a result of an alternative splicing of the original genes.

\section{Production of recombinant GAP peptides}

All three GAP cDNAs were introduced into the bacterial His-tagged protein expression vector, pQE-31. The recombinant GAPs were expressed and purified. Analysis on 17\% PAGE to detect the production of recombinant GAP peptides resulted in clear bands of the expected size of $6.5 \mathrm{kDa}$ for the sea bream and the salmon GAPs. However, no recombinant cIIGAP could be detected. Following the purification process, which included binding to NI-NTA column and elution under denaturing conditions, clear clean bands for both sea bream and salmon GAPs were obtained, with some degradation seen in the late eluting fractions (Fig. 2A and B).

The cIIGAP was engineered into the pGEX $_{2}$ vector and expressed as a fusion protein to glutathione S-transferase (GST). The purification procedure included binding to glutathione-agarose beads and elution with glutathione solution. SDS PAGE analysis of the eluted fractions revealed two bands: the cIIGAP/GST fused protein as a dominant band, $34 \mathrm{kDa}$ in size, and a smaller faint band of $27 \mathrm{kDa}$ which corresponds to the GST protein on its own (Fig. 2C).

\section{Production of antibodies}

The three recombinant GAP proteins were injected into guinea pigs, three animals for each GAP, to obtain polyclonal antibodies. All nine antisera appeared to contain high levels of specific anti-GAP IgGs. As shown in Fig. 3, 
A.

AGTGTGGGAGAGCTAGAGGCAACCATCAGGgtgagtgatttatttattttttatgtgadtgattctacagttca ggaaatgtggtgtcttaatgaaatttaacagaaaatgtaacagaaatacttcagaatgactggcttttttcttattttaagatgctgtatatgttatgtt gggtccagatcttacaccaactttcatctactaaaatctctatttgattgtacttagATGATGGGTACAGGAGAAGTGGTG TCTCTTCCTGAAGAGGCGAGTGCCCAAACCCAAGAGAGACTTAGACCATACAATGTA GTAagtgctcattatacataatttatcaccaatgtctacttcaattgtacaataatgtacactgcaccactgtgtgccactgtgttccaaagcag caatgacaatatacaaactgctcaatgactgttcttattttccctttttgttttattgaatatatgaatgtttaattttatctttctgaatgtaacgctaatt tactcagacttgtttgctatcatgaaaatgaaaattaaatatttcttagattaaatattaaacagaaaatcaactgagatttaatttcacccttcagA TTAATGATGATTCCAGTCATTTTGACCGAAAAAAGAGGTTCCCTAACAAATGA

B.

GAACTGGACTCTTTTGGCACTTCAGAGgttgggatcagtgtttgtgtgtgttttctcattcactgggcatttcetgttgag aatgtagatgttctttacetctttactettctctgtttctcagATTTCGGAGGAGA]TAAGCTGTGTGAGGCAGGA

\author{
GAATGCAGCTATTTGAGACCCCAGAGGAGGAGTGTTCTGAGAAATATCATTgtaagtgga
} ctaacggtacccgatcctgtgctgtatgggagcaggttgtacacagatgccaccttgttgacataatgcccaacatatctatacactggacata actgcaaaacattgtacaatagctgtacattacaagcatagtgtatagtgtgtctgactatcattcttcacagCTGGATGCCTTAGC

\title{
CAGAGAGCTCCAGAAGAGGAAGTAG
}

Figure 1 (A) Nucleotide sequence and the deduced amino acids of the unprocessed form of the salmon GAP cDNA. Lower case nucleotides represent putative intron sequences. Alternative stop codon is shown in the box. (B) Nucleotide sequence and the deduced amino acids of the unprocessed form of the chicken II GAP cDNA. Lower case nucleotides represent putative intron sequences. Alternative stop codon is shown in the box.

results obtained in the dot blot analysis clearly show a strong specific signal of the primary antiserum with its own antigen but no reaction with the two other recombinant proteins.

Immunohistochemistry of GAP-expressing cells and fibers

To ensure that the GAP antibodies were suitable for the localization of preproGnRH expressing structures, the distribution of GAP-immunoreactive (ir) cells were compared with that of the corresponding GAP mRNAs, as detected by in situ hybridization. A very good correspondence between the distribution of GnRH-expressing perikarya and preproGnRH mRNA-containing cells was observed in all brain regions (Fig. 4). Cell bodies containing either sGAP mRNA or protein were mostly detected in the olfactory bulbs, either in the glomerular layer or in the ganglion cells of the terminal nerve (Fig. 4A and D). 

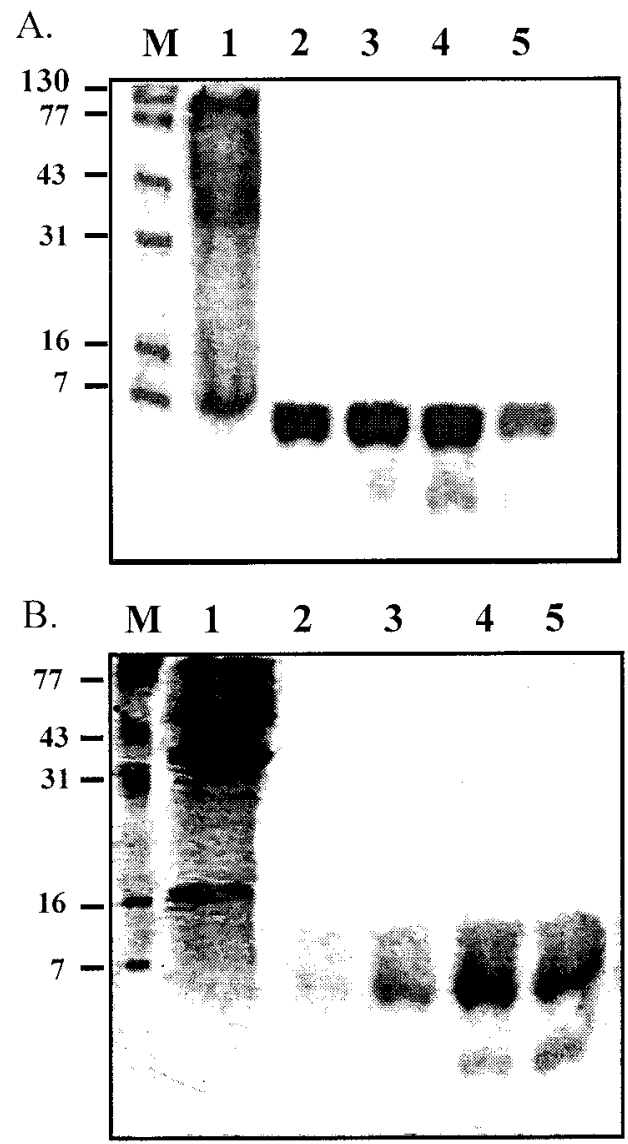

C.

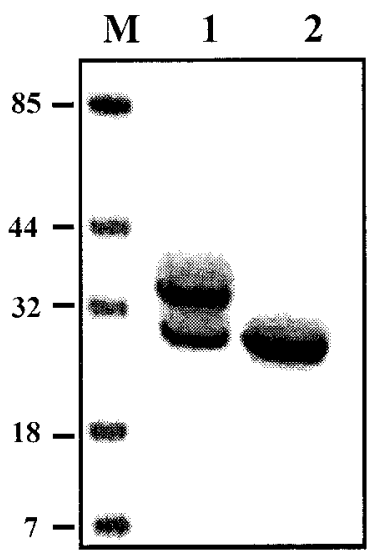

Figure 2 Purification of recombinant GAPs. (A) SGAP purification on NI-NTA column. $M$, molecular standards $\left(M_{r} \times 10^{-3}\right)$; lane 1 , non retained proteins; lanes 2 to 5 , elution fractions 4 to 8 respectively. (B) sbGAP purification on NI-NTA column. M, molecular standards $\left(M_{\mathrm{r}} \times 10^{-3}\right)$; lane 1 , non retained proteins; lanes 2 to 5, elution fractions 4 to 8 respectively. (C) CllGAP purification on gluthathione-agarose column. $M$, molecular standards $\left(M_{r} \times 10^{-3}\right)$; lane 1, eluted cllGAP; lane 2, eluted glutathione-transferase.

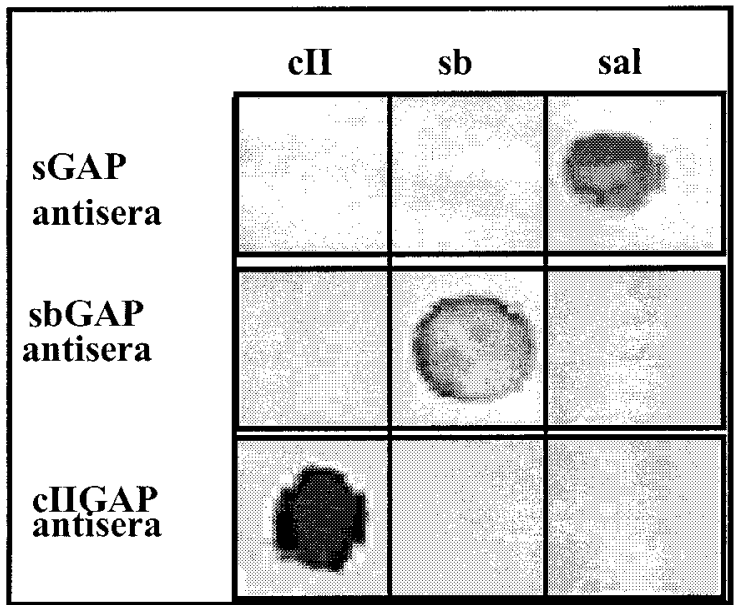

Figure 3 Specificity of GAP antisera. Dot blot analysis of GAP antisera and recombinant GAPs. Each nitrocellulose slice contained 6-12 $\mu \mathrm{g}$ of one recombinant GAP and was reacted with different antisera as indicated. sal, salmon.

Cells expressing sbGAP mRNA or protein were detected in the caudal ventral telencephalon, the ventral preoptic region (Fig. 4B and E) and, more caudally, in the mediobasal hypothalamus. Finally, large cells expressing both cIIGAP mRNA and protein were only detected in the medial longitudinal fascicle of the synencephalon (Fig. $4 \mathrm{C}$ and F). The sGAP-ir fibers were more evident in the olfactory bulbs, ventral telencephalon, preoptic area, dorsal hypothalamus, ventral thalamus, pretectum and dorsal tegmentum. However, a conspicuous sGAP innervation was also observed in the dorsal telencephalon, optic tectum and ventral rhombencephalon. The pituitary gland only receives a relatively small number of sGAP-ir fibers. Sea bream GAP immunoreactive (sbGAP-ir) fibers were observed only in the ventral surface of the forebrain, associated with the ventral telencephalon, preoptic area and hypothalamus. These sbGAP-ir fibers strongly innervate the pituitary gland of sea bass. Finally, chicken-II GAP immunoreactive (cIIGAP-ir) fibers were abundant in the brain of sea bass, being especially evident in dorsal and ventral telencephalon, periventricular preoptic area and hypothalamus, dorsal and ventral thalamus, pretectum, posterior tuberculum, mesencephalic tectum and tegmentum, cerebellum, and rhombencephalon. No cIIGAP-ir fibers were detected in sea bass hypophysis.

\section{Discussion}

In this study, we have cloned three GnRH cDNAs encoding the precursors of three peptides from the European sea bass, providing further information on the presence of three variants in the brain of a perciform fish. Furthermore, we have produced recombinant GAP 

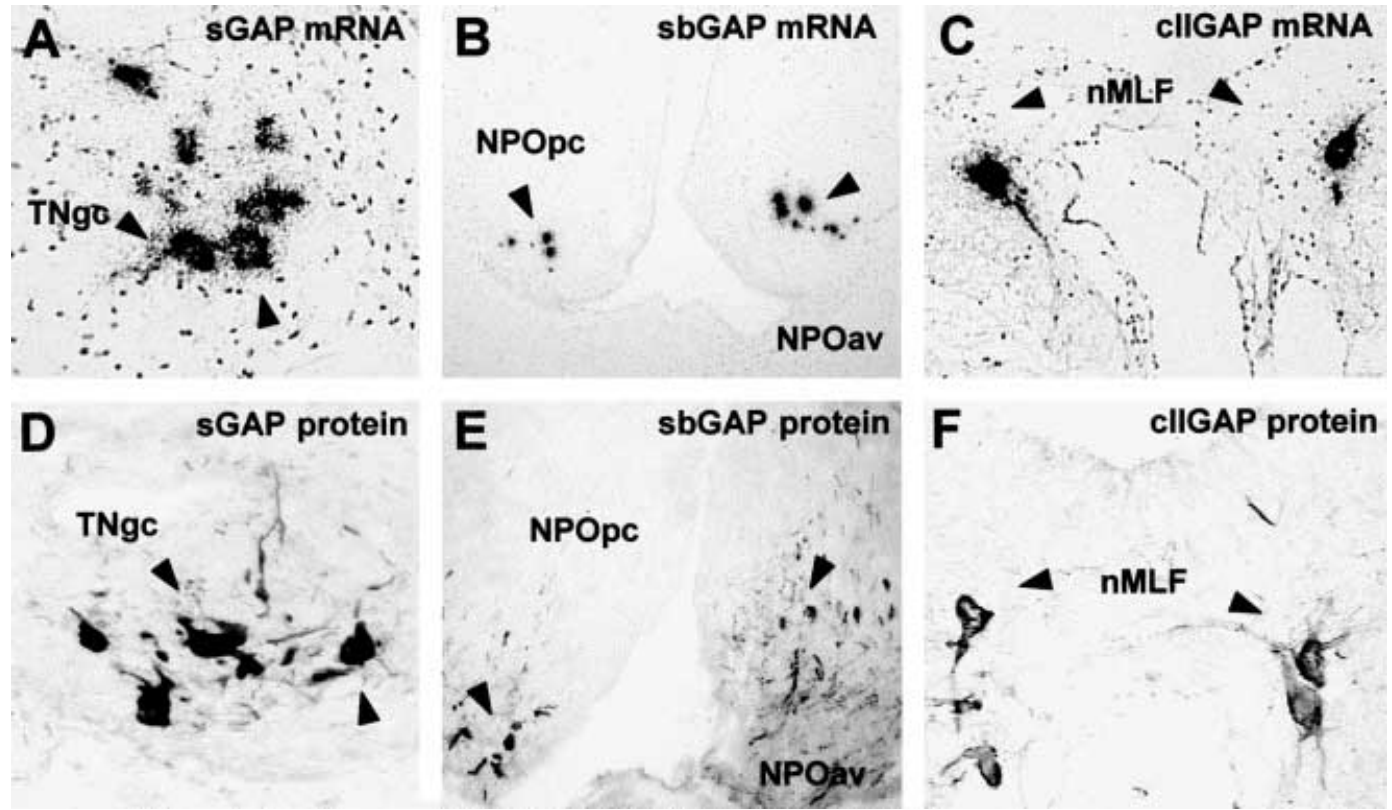

Figure 4 Detection of GnRH-producing neurons in the brain of the sea bass by in situ hybridization $(A, B, C)$ and immunohistochemistry $(\mathrm{D}, \mathrm{E}, \mathrm{F})$. In the olfactory bulb, the ganglion cells of the terminal nerve $(\mathrm{TNgC})$ were consistently shown to express sGAP mRNA $(A, \times 160)$ and protein $(D, \times 160)$. Sea bream mRNA $(B, \times 40)$ and protein $(E, \times 40)$ were detected in numerous cells of the ventral preoptic region (NPOpc, nucleus preopticus pars parvocellularis; NPOav, nucleus preopticus pars anteroventralis), whereas cllGAP mRNA $(\mathrm{C}, \times 100)$ and protein $(F, \times 100)$ were restricted to a group of large neurons in the nucleus of the medial longitudinal fascicle (nMLF). All pictures represent transverse sections.

proteins and raised specific antibodies suitable for the immunohistochemical detection of structures expressing preproGnRH.

The European sea bass $\mathrm{GnRH}$ precursors exhibit the same general organization as all other known GnRH precursors: a signal peptide at the $\mathrm{N}$ terminus, the GnRH decapeptide, a conserved processing tripeptide sequence and the GAP region at the C-terminus. This typical organization suggests that all these preproGnRHs have a common ancestral origin.

The cDNA encoding for the precursors of the sGnRH and the cGnRH II have $87 \%-99 \%$ sequence identity with the corresponding sequences in other perciforms (Table 2, Fig. 5A and $\mathrm{C}$ ). Both the signal peptide and the GAPs are quite conserved. However, the $s b G n R H$ precursor sequence identity was approximately $90 \%$ with the striped bass and dropped to $40-60 \%$ with the sea bream and the African cichlid (Table 2, Fig. 5B). Interestingly, this suggests that the gene coding for the sbGnRH precursor has evolved faster than those coding for sGnRH and cGnRH II and also that sbGAP does not have strong physiological significance.

Two kinds of transcripts were found for the chicken II and salmon GAPs: a processed and an unprocessed form. The existence of introns in GnRH transcripts was previously reported in several studies: in the gilthead sea bream brain, the sGnRH form contains intron 1 as a $5^{\prime}$
UTR (Gothilf et al. 1996). Similarly, the sGnRH expressed in the gonads of the rainbow trout retains intron 1 to generate different sizes of $5^{\prime} \mathrm{UTR}$ (Von Schalburg \& Sherwood 1999). In the ovary of sea bream, sbGnRH and cGnRH II transcripts retained all three introns, and the possibility of an alternate stop codon that changes the GAP amino acid sequence is suggested (Nabissi et al. 2000). In the sea lamprey, three transcripts of the lamprey GnRH I form, differing in the length of GAP coding region due to alternative splicing in intron 2 were reported (Suzuki et al. 2000). In this study, the different transcripts of the cGnRH II and sGnRH were found to be expressed simultaneously in the brain of the European sea bass. Similar to the finding in the sea bream gonads, an alternative stop codon that truncates the amino acid sequences of the GAPs was found. The phenomenon of multiple transcripts of the same GnRH gene suggests that one GnRH form may have different functions.

The recent evidence that the brain of modern teleosts expresses three different GnRH genes encoding three different $\mathrm{GnRH}$ forms raises interesting questions in terms of distribution, functional significance, regulation and ontogenesis. This warrants thorough investigations with respect to the distribution of the cells expressing the different forms and their respective projections in adult animals and throughout development. 
A

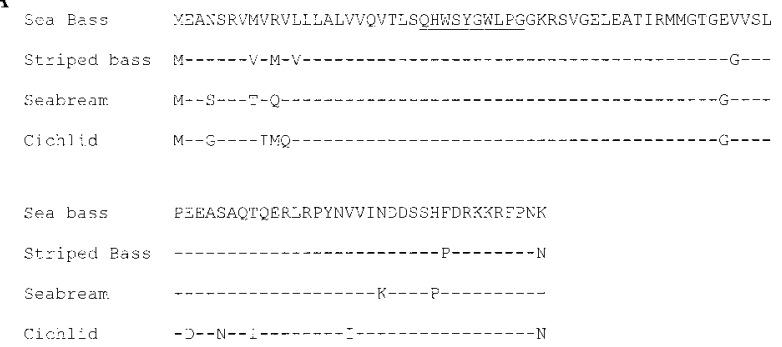

B

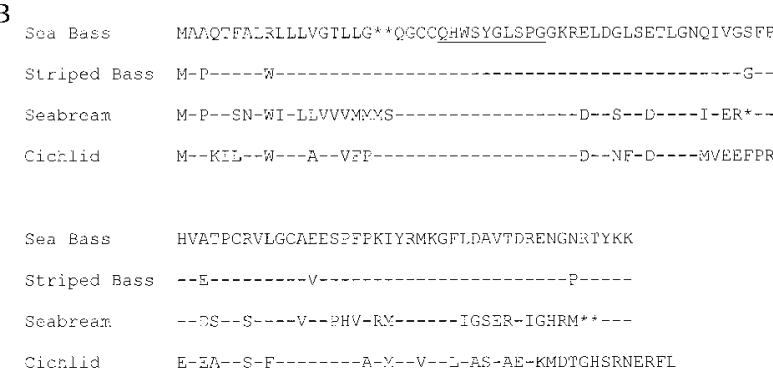

$\mathrm{C}$

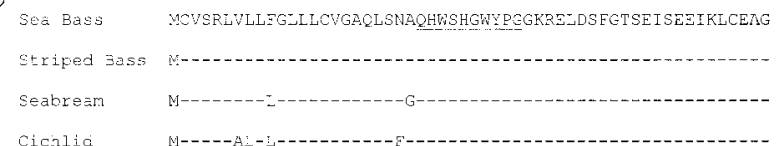

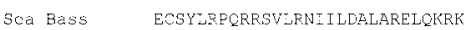

Berined Bass

Seabreatin

cichlid

Figure 5 Comparison of GnRH precursor sequences of perciform representatives with the sea bass precursors. The GnRH decapeptide is underlined. Homologous amino acids are shown as dashes. (A) sGnRH precursor. (B) sbGnRH precursor. (C) $\mathrm{cGnRH}$ II precursor.

Until now, the organization of central GnRH systems has mainly been studied by means of immunohistochemistry using antibodies more or less specific for the endogenous decapeptides. Despite this lack of specificity, this technique has allowed the establishment of the organization of the GnRH systems in teleosts, and the presence of immunoreactive GnRH cells not only in the ventral forebrain, but also in the midbrain tegmentum (Münz et al. 1981, Kah et al. 1986). But specificity turned out to be a critical problem when it became clear that different forms of GnRH were produced in the brain of a single species (Yu et al. 1988). Nevertheless, using wellcharacterized antibodies, several studies succeeded in showing the differential expression pattern of two different GnRHs, for example in the brain of the Masu salmon (Amano et al. 1991), the Siberian sturgeon (Leprêtre et al. 1993), the European eel (Montero et al. 1994) or the goldfish (Kim et al. 1995). The cDNA sequences encoding different $\mathrm{GnRH}$ forms allowed this problem to be approached by using in situ hybridization. This was first achieved in the African catfish to map the cells expressing cfGnRH and cGnRH II by selecting probes corresponding to the highly divergent cfGAP and cIIGAP sequences (Zandbergen et al. 1995).

The present study investigates the differential expression of three GnRH genes at both the mRNA and protein levels. Indeed, the distribution of the cells expressing prepro-sGnRH, -sbGnRH and -cGnRH-II mRNAs has already been studied in different perciforms (White et al. 1995, Gothilf et al. 1996, Okuzawa et al. 1997, Parhar et al. 1998). However, the respective projections of the different cell groups remained unknown. The results of our in situ hybridization study confirm the differential expression of the three forms by showing that sGnRH mRNA is mainly detected in the olfactory bulbs, sbGnRH mRNAs in the preoptic area and cGnRH II in the synencephalon, as shown in other perciforms (White et al. 1995, Gothilf et al. 1996, Okuzawa et al. 1997, Parhar 1997, Parhar et al. 1998, White \& Fernald 1998). Because of the high similarity in the primary sequences of the three corresponding GnRH decapeptides, it was decided to generate antibodies against recombinant GAPs. This enabled us to circumvent the problem of specificity. It also allowed the use of a longer peptide to generate antibodies without any coupling to a carrier protein. The preliminary results obtained with all three antisera designed for each GAP fully confirm the distribution of the corresponding $\mathrm{mR}$ NAs as well as the strict specificity of the antisera. The overall distribution of the GnRH-expressing cells also confirms what was previously reported in the same species using antibodies against sGnRH (Kah et al. 1991). The antibodies used in this latter study most likely recognized both sGnRH and sbGnRH, since the distribution of GnRH cell bodies corresponded exactly to the sum of sGAP- and sbGAP-immunoreactive cells detected in the present work. These results not only demonstrate that translation occurs in the different mRNA-expressing cell groups, but also that antisera against GAPs are suitable to map the different GnRH systems.

In addition to confirming the distribution of the different preproGnRH mRNAs, these antibodies demonstrated that sGAP immunoreactive fibers project mainly to the forebrain, but that a few projections also reach the pituitary. Fibers immunoreactive for sbGAP were mainly observed in the preoptic area, the mediobasal hypothalamus and predominantly project to the pars distalis of the pituitary. The cIIGAP-positive projections are widespread in the brain of sea bass but mainly concerned the posterior brain and did not reach the pituitary. From these results, it is clear that sbGnRH is the most physiologically relevant form with respect to gonadotropin, and that $\mathrm{sbGnRH}$ neurons of the preoptic area and ventral telencephalon are the main sources of the pituitary 
sbGnRH innervation. This assumption is consistent with previous physiological studies performed in another perciform species, the gilthead sea bream (Powell et al. 1994, Gothilf et al. 1996, Holland et al. 1998) as well as in the European sea bass (Rodriguez et al. 2000). Moreover, sbGnRH mRNA levels in the brain of both species were shown to fluctuate in correlation with ovarian development, suggesting their relevance in this process (Gothilf et al. 1997, Rodriguez et al. 2000). However, the present results also indicate a minor contribution of $\mathrm{sGnRH}$ fibers to the pituitary, although the precise origin of these projections remains to be established. In the dwarf gourami, the terminal nerve ganglion cells have been shown to project widely in the brain, but not in the pituitary (Oka \& Matsushima 1993). It is generally believed that GnRH-immunoreactive cells of the terminal nerve are not essential for the regulation of gonadotropin release, an assumption strongly reinforced by the fact that sectioning the olfactory tract in female goldfish does not impair gonadal development and ovulation (Kobayashi et al. 1994). Thus, sGAP-ir fibers entering the pituitary of sea bass could also be involved in the regulation of the functions of other adenohypophyseal cells.

At the present stage, it is not known whether the existence of three GnRH genes in perciforms is the result of recent gene duplication in modern teleosts or if the situation is similar in other fish families or even in other classes of vertebrates. However, recent data obtained in herring also indicate the existence of three $\mathrm{GnRH}$ variants in the brain of this very primitive teleost (Carosfeld et al. 2000), which suggests that this feature could be common to most teleosts. Phylogenetic analyses indicate that sbGnRH-coding sequences form a branch different from that of sGnRH and cGnRH II-coding sequences (J A Muñoz-Cueto \& O Kah unpublished data, Gothilf et al. 1995, White et al. 1998). In addition, there is recent evidence in frog that the brain of amphibians also expresses three forms (Yoo et al. 2000). This suggests that the duplication which gave rise to $\mathrm{sbGnRH}$ is ancient and occurred before the separation of modern fish and tetrapods. Recent studies in mammals based on HPLC using highly specific antibodies support this assumption, indicating that a third $\mathrm{GnRH}$ peptide, possibly sGnRH is expressed in higher vertebrates, including humans (Yahalom et al. 1999). Furthermore, it has been shown in the rhesus macaque that two different populations of GnRH-immunoreactive neurons differentiate during development with different morphological features and a different final distribution in the brain (Quanbeck et al. 1997). On the other hand, a recent study based on promoter transgenics in mice suggests the existence of different GnRH neuronal populations of different embryological origins during development (Skynner et al. 1999).

Altogether, our results indicate that the molecular and immunological tools generated in the sea bass are highly specific and are suitable for future studies aimed at investigating the development, organization, regulation and functional significance of three GnRH systems in the brain of a single species.

\section{Acknowledgements}

We would like to acknowledge the expert advice and technical help of Dr Yoav Gothilf and Dr Iris Meiri. This work was supported by a grant from the European Union (FAIR CT97-3785).

\section{References}

Amano M, Oka Y, Aida K, Okumoto N, Kawashima S \& Hasegawa Y 1991 Immunocytochemical demonstration of salmon $\mathrm{GnRH}$ and chicken GnRH-II in the brain of Masu salmon, Oncorhynchus masou. Journal of Comparative Neurology 314 587-597.

Anglade I, Zandbergen T \& Kah O 1993 Origin of the pituitary innervation in the goldfish. Cell and Tissue Research 273 345-355.

Bloch B, Gaillard RC, Culler MD \& Negro-Vilar A 1992

Immunohistochemical detection of proluteinizing hormone-releasing hormone peptides in neurons in the human hypothalamus. Journal of Clinical Endocrinology and Metabolism 74 135-138.

Burgus R, Butcher M, Amoss M, Ling N, Monaham M, Rivier J, Fellows R, Blackwell R, Vale W \& Guillemin R 1972 Primary structure of the ovine hypothalamic luteinizing hormone releasing factor (LRF). PNAS 69 278-282.

Carosfeld J, Powell JF, Park M, Fischer WH, Craig AG, Chang JP, Rivier JE \& Sherwood NM 2000 Primary structure and function of three gonadotropin-releasing hormones, including a novel form, from an ancient teleost, herring. Endocrinology 141 505-512.

Chomczynski P \& Sacchi N 1987 Single step method of RNA isolation by acid guanidinium thiocyanate-phenol-chloroform extraction. Analytical Biochemistry 162 156-159.

Chow MM, Kight KE, Gothilf Y, Alok D, Stubblefield J \& Zohar Y 1998 Multiple GnRHs present in a teleost species are encoded by separate genes: analysis of the sbGnRH and cGnRH II genes from the striped bass, Morone saxatilis. Journal of Molecular Endocrinology 21 277-289.

Frohman MA 1990 RACE: rapid amplification of cDNA ends. In PCR Protocols: A Guide to Methods and Applications, pp 28-38. Eds MA Innis, DH Gelfand, JJ Sninsky \& TJ White. New York: Academic Press.

González-Martínez D, Madigou T, Zmora N, Anglade I, Zanuy S, Zohar Y, Elizur A, Muñoz-Cueto JA \& Kah O 2001 Differential expression of three different prepro-GnRH (gonadotrophinreleasing hormone) messengers in the brain of the European sea bass (Dicentrarchus labrax). Journal of Comparative Neurology 429 144-155.

Gothilf Y, Elizur A, Chow M, Chen TT \& Zohar Y 1995 Molecular cloning and characterization of a novel gonadotropin-releasing hormone from the gilthead seabream (Sparus aurata). Molecular Marine Biology and Biotechnology 4 27-35.

Gothilf Y, Muñoz-Cueto JA, Sagrillo CA, Selmanoff M, Chen TT, Elizur A, Kah O \& Zohar Y 1996 Three forms of gonadotrophinreleasing hormone in a teleost fish: cDNA characterization and brain localization. Biology of Reproduction 55 636-645.

Gothilf Y, Meiri I, Elizur A \& Zohar Y 1997 Preovulatory changes in the levels of three gonadotropin-releasing hormone-encoding messenger ribonucleic acids (mRNAs), gonadotropin betasubunit mRNAs, plasma gonadotropin, and steroids in the female 
gilthead seabream, Sparus aurata. Biology of Reproduction $\mathbf{5 7}$ $1145-1154$.

Holland MCH, Gothilf Y, Meiri I, King JA, Okuzawa K, Elizur A \& Zohar Y 1998 Levels of the native forms of GnRH in the pituitary of the gilthead seabream, Sparus aurata, at several characteristic stages of the gonadal cycle. General and Comparative Endocrinology 112 394-405.

Kah O, Breton B, Dulka JG, Nunez-Rodríguez J, Peter RE, Corrigan A, Rivier JE \& Vale WW 1986 A reinvestigation of the $\mathrm{GnRH}$ (gonadotrophin-releasing hormone) systems in the goldfish brain using antibodies to salmon Gn-RH. Cell and Tissue Research 244 327-337.

Kah O, Zanuy S, Mañanos E, Anglade I \& Carrillo M 1991 Distribution of salmon gonadotrophin-releasing hormone in the brain and pituitary of the sea bass (Dicentrarchus labrax). Cell and Tissue Research 266 129-136.

Kim MH, Oka Y, Amano M, Kobayashi M, Okuzawa K, Hasegawa Y, Kawashima S, Suzuki Y \& Aida K 1995 Immunocytochemical localization of sGnRH and cGnRH-II in the brain of goldfish, Carassius auratus. Journal of Comparative Neurology 356 72-82.

Klungland $\mathrm{H}$, Lorens JB, Anderson O, Kisen GO \& Alestrom P 1992 The Atlantic salmon prepro-gonadotropin releasing hormone gene and mRNA. Molecular and Cellular Endocrinology 84 167-174.

Kobayashi M, Amano M, Kim MH, Furukawa K, Hasegawa Y \& Aida K 1994 Gonadotropin-releasing hormones of terminal nerve origin are not essential to ovarian development and ovulation in goldfish. General and Comparative Endocrinology 95 192-200.

Leprêtre E, Anglade I, Williot P, Vandesande F, Tramu G \& Kah O 1993 Comparative distribution of mammalian $\mathrm{GnRH}$ (Gonadotrophin-Releasing Hormone) and chicken GnRH-II in the brain of the immature Siberian sturgeon (Acipenser baeri). Journal of Comparative Neurology 337 568-583.

Matsuo H, Baba Y, Nair RMG, Arimura A \& Schally AV 1971 Structure of the porcine LH- and FSH-releasing hormone. I. The proposed amino acid sequences. Biochemical and Biophysical Research Communications 43 1334-1339.

Miyamoto K, Hasegawa Y, Nomura M, Igarashi M, Kangawa K \& Matsuo H 1984 Identification of the second gonadotropin releasing hormone in chicken hypothalamus: evidence that gonadotropin secretion is probably controlled by two distinct gonadotropin releasing hormones in avian species. PNAS $\mathbf{8 1}$ 3874-3878

Montero M, Vidal B, Vandesande F, King JA, Tramu G, Dufour S \& Kah O 1994 Comparative distribution of mammalian $\mathrm{GnRH}$ (Gonadotrophin-Releasing Hormone) and chicken GnRH-II in the brain of the European eel. Journal of Chemical Neuroanatomy 7 227-241.

Münz HP, Stumpf WE \& Jennes L 1981 LHRH systems in the brain of platyfish. Brain Research 221 1-13.

Nabissi M, Soverchia L, Polzonetti-Magni AM \& Habibi HR 2000 Differential splicing of three gonadotropin releasing hormone transcripts in the ovary of sea bream (Sparus aurata). Biology of Reproduction 62 1329-1334.

Ngamvongchon S, Lovejoy DA, Fischer WH, Craig AG, Nahorniak CS \& Sherwood NM 1992 Primary structure of two forms of gonadotropin-releasing hormone, one distinct and one conserved, from catfish brain. Molecular and Cellular Neuroscience 3 17-22.

Oka Y \& Matsushima T 1993 Gonadotrophin-releasing hormone $(\mathrm{GnRH})$-immunoreactive terminal nerve cells have intrinsic rhythmicity and project widely in the brain. Journal of Neuroscience 13 2161-2176.

Okubo K, Amano M, Yoshiura Y, Suetake H \& Aida K 2000 A novel form of gonadotropin-releasing hormone in the medaka, Oryzias latipes. Biochemical and Biophysical Research Communications 276 298-303.
Okuzawa K, Granneman J, Bogerd J, Goos HJTh, Zohar Y \& Kagawa H 1997 Distinct expression of GnRH genes in the red seabream brain. Fish Physiology and Biochemistry 17 71-79.

Parhar IS 1997 GnRH in tilapia: three genes, three origins and their roles. In GnRH Neurons: Gene to Behavior, pp 99-122. Eds IS Parhar \& Y Sakuma. Tokyo: Brain Shuppan.

Parhar IS, Soga T, Ishikawa Y, Nagahama Y \& Sakuma Y 1998 Neurons synthesizing gonadotropin-releasing hormone mRNA subtypes have multiple developmental origins in the medaka. Journal of Comparative Neurology 401 217-226.

Polkowska J \& Przekop F 1993 Effect of protein deficiency on luteinizing hormone releasing hormone (LHRH), gonadotropin releasing hormone associated peptide (GAP) and luteinizing hormone (LH) immunocytochemistry in the hypothalamus and pituitary gland of prepubertal ewes. Experimental and Clinical Endocrinology 101 230-237.

Powell JFF, Zohar Y, Elizur A, Park M, Fischer WH, Craig AG, Rivier JE, Lovejoy DA \& Sherwood NM 1994 Three forms of gonadotropin-releasing hormone characterized from brains of one species. PNAS 91 12081-12085.

Quanbeck C, Sherwood NM, Millar RP \& Terasawa E 1997 Two populations of luteinizing hormone-releasing hormone neurons in the forebrain of the rhesus macaque during embryonic development. Journal of Comparative Neurology 380 293-309.

Rodriguez L, Carrillo M, Sorbera LA, Soubrier MA, Mananos E, Holland MC, Zohar Y \& Zanuy S 2000 Pituitary levels of three GnRH in the male European sea bass (Dicentrarchus labrax L.) during sex differentiation and first spawning season. General and Comparative Endocrinology 120 67-74.

Ronchi E, Aoki C, Krey LC \& Pfaff DW 1992 Immunocytochemical study of $\mathrm{GnRH}$ and $\mathrm{GnRH}$-associated peptide in male Syrian hamsters as a function of photoperiod and gonadal alterations. Neuroendocrinology 55 134-145.

Sherwood N, Eiden L, Brownstein M, Spiess J, Rivier J \& Vale W 1983 Characterization of a teleost gonadotropin-releasing hormone. PNAS 80 2794-2798.

Sherwood NM, Parker DB, McRoy JE \& Leischeid DW 1994 Molecular evolution of growth hormone-releasing hormone and gonadotropin-releasing hormone. In Fish Physiology, vol 13, pp 3-66. Eds NM Sherwood \& CL Hew. San Diego: Academic Press.

Skynner MJ, Slater R, Sim JA, Allen ND \& Herbison AE 1999 Promoter transgenics reveal multiple gonadotropin-releasing hormone-I-expressing cell populations of different embryological origin in mouse brain. Journal of Neuroscience 19 5955-5966.

Sower SA 1997 Evolution of GnRH in fish of ancient origins. In GnRH Neurons: Gene to Behavior, pp 27-50. Eds IS Parhar \& Y Sakuma. Tokyo: Brain Shuppan.

Suzuki K, Gamble RL \& Sower SA 2000 Multiple transcripts encoding lamprey gonadotropin releasing hormone-I precursors. Journal of Molecular Endocrinology 24 365-376.

Von Schalburg KR \& Sherwood NM 1999 Regulation and expression of gonadotropin releasing hormone gene differs in brain and gonads in rainbow trout. Endocrinology 140 3012-3024.

White RB \& Fernald RD 1998 Genomic structure and expression sites of three gonadotropin-releasing hormone genes in one species. General and Comparative Endocrinology 112 17-25.

White SA, Kasten TL, Bond CT, Adelman JP \& Fernald RD 1995 Three gonadotropin-releasing hormone genes in one organism suggest novel role for an ancient peptide. PNAS 92 8363-8367.

White RB, Eisen JA, Kasten TL \& Ferland RD 1998 Second gene for gonadotropin-releasing hormone in humans. PNAS 95 305-309.

Yahalom D, Chen A, Ben Aroya N, Rahiminpur S, Aganovsky E, Okon E, Fridkin M \& Koch Y 1999 The gonadotropin-releasing hormone family of neuropeptides in the brain of human, bovine and rat: identification of a third isoform. FEBS Letters 463 289-294.

Yoo MS, Kang HM, Choi HS, Kim JW, Troskei BE, Millar RP \& Kwon 2000 Molecular cloning, distribution and pharmacological 
characterization of a novel gonadotropin-releasing hormone ([Trp8] $\mathrm{GnRH})$ in frog brain. Molecular and Cellular Endocrinology 164 197-204.

Yu KL, Sherwood NM \& Peter RE 1988 Differential distribution of two molecular forms of gonadotropin-releasing hormone in discrete brain areas of goldfish (Carassius auratus). Peptides 9 625-630.
Zandbergen MA, Kah O, Bogerd J, Puete J \& Goos HJTh 1995 Expression and distribution of two gonadotropin-releasing hormones in the catfish brain. Neuroendocrinology 62 571-578.

Received in final form 6 September 2001 Accepted 19 September 2001 